УДК 2:29; 477-3:32.323

\section{Юлія Філь}

\section{Міжнародне товариство свідомості Кришни (ISKCON) В період війни на Донбасі (2014 - 2019)}

Анотація. Міжнародне товариство свідомості Кришни в Україні з початком війни на Донбасі зіткнулося як з практичними, так і 3 світоглядними викликами. Практичні були пов'язані 3 організацією допомоги біженцям-одновірцям, а духовні із формулюванням власного ставлення до війни як на рівні керівництва громади, так і на індивідуальному рівні. На практичний виклик громада відповіла заснуванням фонду допомоги біженцям, який забезпечив будівництво нового тимчасового житла для постраждалих від конфлікту й займався утепленням непристосованих для холодного сезону житлових приміщень ашрамів ISKCON.

Що стосується світоглядного виклику, то позиція ISKCON як релігійної організації стосовно подій на Сході України однозначна і передбачувана: вайшнавська громада жодним чином не втручається у справи війни і не приймає жодну із сторін. Це пов'язано зі специфічним баченням війни у вайшнавізмі та власної ролі у ній. По-перше, вайшнавізм принщипово розділяє матеріальний та духовний (трансцендентний) світи, тому мирські проблеми (включаючи війни) $є$ менше важливими та цінними, ніж духовні. По-друге, індуїстське сприйняття часу передбачає, що зараз світ переживає період деградації - калі-югу, коли війни є невідворотними і ніхто не може на це вплинути, а тому брати активну участь у війні без нагальної потреби немає жодного сенсу. Звідси випливає специфічне бачення своєї місії у час війни, яка полягає не у прийнятті тієї чи іншої сторони і допомоги їй, а роботу 3 суспільною свідомістю 3 трансформації якості невігластва в якість благості. А така робота передбачає перш за все трансцендентні, а не «мирські», методи. Тому єдиними допустимими «мирським» методами допомоги у ситуації війни став благодійний проект «Їжа життя. Донецьк» та турбота про покинутих в зоні конфлікту корів.

Утім, індивідуальна позиція кожного відданого могла збігатися з позищією ISKCON, а могла відрізнятися від неї в залежності від особистого досвіду вайшнава, особливо до приходу в Свідомість Кришни. Серед вайшнавів зустрічаємо і проукраїнські, i проросійські погляди - кришнаїти в своєму ставленні до війни нічим не вирізняються серед решти населення України. Тому їхня позиція відповідає позиції населення в цілому на тих чи інших територіях. 3 відомих причин кожну з позицій - проукраїнську і проросійську - більше чути 3 того чи іншого боку від лінії розмежування, в той час як протилежну не афішують або замовчують. Вайшнави успішно відповіли на світоглядний виклик як на рівні громади, так і на індивідуальному рівні. По-перше, у громадах майже не відбулося розколів (відомо, що лише деякі ятри на непідконтрольних Україні територіях близькі до розколу); по-друге, вайшнави по обидва боки від лінії розмежування не припинили спілкуватися між собою, так само як не припинили спілкування 3 вайшнавами Криму, по-третє, воєнний конфлікт на Сході України не завадив контактам та дружньому ставленню одне до одного українських та російських вайшнавів. Хоча 
інтенсивність таких контактів зменшилася, але радше через технічні причини, пов'язані $з$ труднощами перетину кордону, ніж через світоглядні причини.

Перед громадами на непідконтрольних Україні територіях, а також в Криму постали практичні турботи легалізації в умовах жорсткого релігійного законодавства.

Ключові слова: вайшнавізм, Міжнародне товариство свідомості Кришни; війна, Донбас, війна на Сході України.

\section{Yulia Fil}

\section{International Society for Krishna Consciousness (ISKCON) in the time of War in Donbas (2014 - 2019)}

\footnotetext{
Abstract. International Society for Krishna Consciousness (ISKCON) in Ukraine faces different kinds of challenges - practical as well as spiritual - since the war in Donbas has started. The practical challenge is connected with taking care of fellows believers from war areas. The spiritual one concerns what the community stood for in the conflict. The response to the first one was the foundation of «Ukrainian Vaishnava Refugee Fund» which provides temporal shelter for the refugees and makes the premises in Vaishnava retreat centers ready for the cold season. Concerning the second challenge - ISKCON claims principal and conscious detachment from the war. One could not expect different positions from this religious organization taking to account its theological particularities of the religion. Firstly, Vaishnavism claims a strong division of reality into material and spiritual (transcendental) worlds so that worldly matters including wars are treated as less important
}

and valuable. Secondly, the Hindu perception of time implies that Earth is facing the period of degradation (kali yuga) when wars are inevitable and no one can influence them, so there is no point in active participation in them. Thirdly, Vaishnavism does not think about its position on war as the detachment rather it claims a different type of participation which derives from the understanding of its mission in any conflict which differs from missions of other religious organizations. The mission of ISKCON in the war is not to take one or another side but to transform the quality of ignorance (tama-guna) into the quality of goodness (sattva-guna) which is reached by transcendental, not worldly methods. Therefore, any ISKCON charity project does not deal with the help to one or another side of the conflict directly but strives to be universal and provide help irrespective to war affairs. As a result of this position, only two ways of charity was possible for the Krishnaites in a wartime - the project «Food for life. Donbas» and taking care of abandoned cows in the conflict zone.

However, the individual position of devotee could differ from organization's one. Usually it depends on his or her personal experience or background, especially before coming to Krishna's consciousness. There are devotees who follow pro-Ukrainian position as well as those who follow pro-Russian, thus Vaishnavas' attitude to the conflict reflects, in general, the Ukrainian population's attitude to it on particular territories. It does not mean that devotees on the Ukrainian territories are all pro-Ukrainian and those who are on the uncontrolled territories are all pro-Russian. Both positions exist on the both sides of the frontline. But because of certain reasons one or another position is louder on one side of the frontline and almost silent on another. 
It could be concluded that Vaishnavas accepted the spiritual challenge successfully on both collective and individual level. As field work has shown ISKCON avoided inner conflicts and schism on the political ground. Furthermore, Ukrainian Vaishnavas have not lost the connection with their fellow believers on the uncontrolled territories. Moreover, they also have not lost the good relationships and connections with Russian fellow believers. Though the intensity of such contacts decreased drastically it is more due to technical reasons connected with the difficulties on the borders. Regarding ISKCON yatras on the uncontrolled territories of Donbas and in Crimea, they are facing difficulties with selflegalization due to strict religious laws.

Key words: Vaishnavism; International Society for Krishna Consciousness; war; Donbas, war in Donbas.

Постановка проблеми. Міжнародне товариство свідомості Кришни (International Society for Krishna Consciousness, далі ISKCON) - найбільш численна нова релігійна організація орієнталістського походження на території України. Згідно 3 даними Департаменту у справах релігій та національностей Міністерства культури України за 2019 рік, в Україні $є 44$ релігійні організації Товариства свідомості Кришни (серед них 39 діючих і 5 центрів управління; 70 священнослужителів, серед яких 1 іноземець; 3 духовних навчальних заклади, 7 недільних шкіл; 2 друкованих видання, 2 електронних видання) [Звіт 2018].

Статистика свідчить про зростання кількості організацій Товариства Свідомості

\footnotetext{
${ }^{1}$ Ятрою у вайшнавізмі називають не лише колісничний фестиваль, але і громаду. Найчастіше ятри збігаються 3
}

Кришни в Україні. Для порівняння станом на 1 січня 2010 року (10 років тому) в Україні було 32 релігійні організації Товариства (серед них 7 незареєстрованих; 1 центр; 5 управлінь; 43 священнослужителі, серед яких 1 іноземець; 3 духовних навчальних заклади; 11 недільних шкіл і 2 періодичних видання) [Релігійні організації 2008]. Тобто, за 10 років в Україні стало на 12 громад Товариства більше. Після початку війни на Сході України кількість громад зменшилась на 4 через втрату громад міста Донецька, Луганська та інших. Якщо станом на 1 січня 2014 року в Україні було 42 громади, то на 1 січня 2015 року їх стало 38. Політичні події на Донбасі стали викликом для вайшнавських громад як на українських, так і на непідконтрольних Україні територіях.

Основний виклад. Донбас, так само як і Крим, характеризуються значним конфесійним різноманіттям. Товариство свідомості Кришни є частиною цього різноманіття. На кінець 2014 у Донецькій області (включаючи окуповані території) було зареєстровано 1795 релігійних організацій, з яких 1723 - релігійні громади. Православні релігійні організації складали біля 49 \%, протестанти всіх напрямків мали більше 700 організацій - 40,9 \% від загальної чисельності. Також в області зареєстровано 38 мусульманських, 19 юдейських, 14 буддійських і 8 вайшнавських релігійних організацій [Карпицкий 2018: 54]. Незважаючи на те, що значна кількість вайшнавів виїхала 3 Донецька після того, як Україна втратила контроль над містом, ятра ${ }^{1}$ не припинила своє існування i продовжує діяти в

адміністративним поділом країни, тому під “ятрою» мається на увазі громада того чи іншого населеного пункту - ятра Донецька, рівненська ятра тощо. 
Донецьку. Президент донецького храму став живим прикладом того, що громада не втратила зв 'язку з відданими на інших територіях України, адже поговорити з ним вдалося під час його візиту у храм міста Бердянська.

Президент повідомив, що громада у Донецьку перебуває зараз на стадії перереєстрації. Закон «Про свободу віровизнання та релігійні об’єднання» у т. зв. Донецькій народній республіці з'явився лише 24 червня 2016 року. До цього релігійне життя регламентувалося конституцією т. зв. ДНР, прийнятою 14 травня 2014 року. У iï преамбулі йшлося про те, що Верхова рада приймає конституцію, «сповідуючи Православну віру (Вipy Християнську Православну Кафолічну Східного Сповідання) Російської православної Церкви (Московський Патріархат) і визнаючи іï основою основ «русского мира». В 9 главі тієї конституції прямо йшлося про те, що в т. зв. ДНР першою $\mathrm{i}$ домінуючою вірою $\epsilon$ Православна віра, сповідувана Російською Православною Церквою (Московського патріархату) [Карпицкий 2018: 54]. Фактично, православ'я (маючи на увазі лише церкву Московського патріархату) було проголошене державною релігією. Пізніше ця «конституція» повністю зникла 3 сайтів т. зв. ДНР, тому інформацію про неї знаходимо лише в посиланнях інших авторів, які ще встигли ознайомитися з нею на сайті псевдореспубліки. Керуючись такою конституцією, нова «влада» влаштувала гоніння на адептів усіх релігій, крім прихильників православної церкви Московського патріархату. Відомі численні приклади захоплення церковних будівель різних релігійних організацій. Пастор церкви «Асамблея Божа» в Донецьку Сергій Косяк 30 грудня 2014 року навів відомі свідчення про захоплення протестантських церков. У травні 2014 року сепаратисти захопили церковні будівлі в Горлівці та Сніжному, а в Донецьку - реабілітаційний центр «Вечірнє світло», взявши 29 людей в полон і побивши деяких реабілітантів [Косяк 2018: 197].

Вайшнавська громада не втратила храм, проте, за свідченнями Миколая Карпіцького, дослідника релігійних общин в умовах війни на сході України, запрошеного експерта в суді про визнання книги «Бгагават-гіта як вона є» екстремістською (м. Томськ, Російська Федерація), були одиничні випадки викрадення та тортур вайшнавів. Респонденту достеменно відомо про щонайменше два таких. Одновірцям вдалося визволити одного полоненого. Вайшнави віддали перевагу не розповсюджувати інформацію про репресії, щоб не завадити запуску благодійної програми «Їжа життя. Донецьк», в рамках загальної соціальної місії ISKCON «Їжа життя», яка була спрямована на допомогу населенню Донбасу в умовах війни [Пища]. Тоді ще місцева «влада» придивлялася до вайшнавів, не знаючи, чого можна очікувати від них. Але невдовзі зрозуміла, що адепти цієї релігії, на відміну від християн, займають позицію невтручання в політичні справи, живуть, за їхніми словами, «в своєму трансцендентному світі», а тому не несуть загрози, ба більше, є вигідними для неї в умовах гуманітарної кризи. Регулярно годуючи гарячими обідами соціально незахищені прошарки населення Донбасу, вайшнави тим самим допомагають покращити гуманітарну ситуацію в регіоні воєнного конфлікту. У 2015 році волонтерські групи «Їжа життя. Донецьк» діяли як на підконтрольних Україні територіях Донбасу (Краматорськ, Маріуполь), так і на непідконтрольних. Пізніше кришнаїти 
зазнавали репресій, але не за релігійною ознакою, а випадково на рівні 3 усіма іншими жителями непідконтрольних територій. 29 серпня 2014 року «Український фонд допомоги вайшнавським біженцям» (Ukrainian Vaisnava Refugee Fund) повідомив, що жоден з відданих не був поранений чи вбитий у конфлікті [Ukrainian Vaishnava].

Закон 2016 року забов'язав усі релігійні об’єднання «ДНР» пройти реєстрацію [Закон 2016]. Частково з цим, а частково 3 воєнними діями на Донбасі пов'язане припинення будь-якої публічної діяльності кришнаӥтської громади. Президент донецького храму А. дас повідомив, що харінами르 та розповсюдження літератури в Донецьку до завершення бойових дій проводитися не будуть. «Зараз сказали, що поки воєнні дії не закінчаться, то не варто цього робити», повідомив президент. Були ідеї провести в Донецьку фестиваль, до якого могли би долучитися громади Луганська, Донецька, Алчевська. Навіть домовленості 3 деякими духовними вчителями вже були. Але в умовах війни та під час перереєстрації такі ідеї не змогли бути реалізовані.

Процедура реєстрації, за словами президента, складніша за ту, яка була раніше за українським законодавством. Закон, прийнятий 24 червня 2016 року, передбачав, що «місцевою релігійною організацією визнається релігійна організація, яка складається не менше, ніж 3 n'ятдесяти (виділення авт.) членів, які досягли віку вісімнадцяти років і постійно проживають в одній місцевості чи в одному населеному пункті» (Стаття 8, частина 3), та «централізованою

\footnotetext{
2 Харінама - хода зі співами і танцями, яка зазвичай відбувається в найбільш відвідуваних місцях міста (на
}

релігійною організацією визнається релігійна організація, яка складається, відповідно до свого статуту i (або) конфесійним нормам не менше, ніж з десяти (виділення авт.) місцевих релігійних організацій» (стаття 8, частина 4). Фактично, йшлося про те, що в донецькій ятрі має бути не менше п'ятдесяти членів, а на території т. зв. ДНР має бути щонайменше десять ятр. Очевидно, що таке законодавство виключало можливість реєстрації вайшнавської організації в т. зв. ДНР, адже на непідконтрольних Україні частинах Донбасу просто не знайдеться такої кількості населених пунктів, де би могли діяти місцеві організації, тобто окремі ятри. На момент розмови (липень 2019 р.) донецька громада перебувала у статусі «тимчасово зареєстрованої», подавши документи на реєстрацію. Втім, релігійне законодавство під кінець 2019 року частково лібералізувалося. У закон були внесені зміни, які стосувалися кількості членів місцевої релігійної організації та централізованої релігійної організації - від 11 жовтня 2019 року місцева релігійна організація мала складатися не менше, ніж 3 десяти членів, а централізована не менше, ніж 3 трьох місцевих релігійних організацій. Враховуючи ці зміни, донецька ятра має безперешкодно пройти реєстрацію. Зараз донецька громада збирає кошти на ремонт та реконструкцію храму, який існує вже більше 25 років. На недільні програми в храм приходить більше 120 людей, а на свята збирається 200 [Проект].

На території так званої Луганської народної республіки зі свободою віровизнання ситуація складніша. Закон «Про

головних площах, в парках) для проповіді і оспівування імені Кришни. 
свободу віровизнання та релігійні об'єднання» від 2 лютого 2018 р. передбачає [Закон 2018], що релігійні об’єднання можуть бути створені лише в формі релігійної організації (Стаття 6, частина 2). Про релігійні групи не йдеться, а це означає, що велика кількість релігійних груп не зможе легалізуватися. Місцевою релігійною організацією визнається релігійне об́єднання, яке складається не менше ніж 3 тридцяти учаників, які досягли вісімнадцятирічного віку і постійно проживають в рамках однієї адміністративно-територіальної одиниці «ЛНР». Централізованою релігійною організацією визнається об'єднання, яке складається не менше ніж 3 п'яти місцевих релігійних організацій. Також законодавство «ЛНР» забороняє проводити богослужіння та інші релігійні обряди та церемонії в житлових приміщеннях, що також сприяє тому, що поза законом опиняються всі релігійні групи, які збираються в оселях одновірців.

Відомо, що кримські вайшнави, так само, як і донецькі, харінами не проводять. Ймовірно, це пов'язано з доданням Глави III.1 «Місіонерська діяльність» до закону Російської Федерації «Про свободу совісті та релігійні об’єнання» від 26 вересня 1997 року № 125-Ф3 [Федеральный закон 2019] в рамках так званого «Пакету Ярової», який нібито має антитерористичну спрямованість. У цьому пакеті було прийнято федеральний закон «Про внесення змін у Федеральний закон «Про протидію тероризму» і окремі законодавчі акти Російської Федерації в частині встановлення додаткових заходів протидії тероризму та гарантування суспільної безпеки» від 6 липня 2016 року № 374-Ф3 [Федеральный закон 2016], в якому і з'явилася вищезгадана глава. Вона, серед іншого, передбачає відповідальність за ведення місіонерської діяльності без наявності документу від організації, яка уповноважує особу займатися місіонерською діяльністю. Ця вимога, як і низка інших, швидше за все, утруднює проведення вайшнавами публічних заходів, які місцева влада, ймовірно, трактує як місіонерську діяльність. Взагалі в Росії, за словами Магабуддгі даса, відданого з Санкт-Петербургу, після суду над книгою «Бгагават-гіта як вона є» в Томську 2011 р. вайшнавів залишили в спокої, вони у більшості випадків безперешкодно проводять харінами й решту публічних заходів. Проблеми можуть виникати в окремих населених пунктах лише у випадку, якщо місцева влада вирішить інтерпретувати харінами як місіонерську діяльність. Це не означає, що вайшнавів переслідують цілеспрямовано, а радше може бути пояснене потребою пошуків правопорушників для статистики.

Вайшнави як донецької, так і луганської ятри підтримують зв'язки з одновірцями на інших територіях України. За словами А. даса, вайшнави з непідконтрольних Україні територій їздять на фестивалі, які проводяться як на території Росії, так i на території України. Але відвідувати українські фестивалі стали менше головним чином через технічні труднощі, пов'язані 3 блокпостами на тимчасових кордонах:

«Складніше стало через блокпости, якщо в бік України їхати. I дорожче це. Проте, їздяь. $Є$ допомога деяка, взаємодопомога. I туди, і туди, якщо фінансова ситуація не дозволяє поїхати на фестиваль, то допомагають і там, і там. Всі помірно допомагають, щоб знайти засоби, пожертвування для нас, щоб ми могли з їздити», - розповідає А. дас. Ізольованою громада Донецька себе не відчуває головно завдяки фестивалям. Від- 
дані $з$ українських територій також відвідують громади на непідконтрольних територіях. Відданий К. дас з Донеччини регулярно їздить в донецький храм для спілкування 3 одновірцями та для догляду за земельною ділянкою біля храму. Також проект «Їжа життя. Донецьк» з 2015 року почав діяти i на контрольованих Україною територіях Донбасу, об'єднавши зусилля 3 волонтерами Краматорська та Маріуполя.

Очевидно, що політичні причини не стали на заваді контактам вайшнавів на непідконтрольних територіях 3 одновірцями на решті територій України. Втім, світоглядні розходження теж є. Мадхава Кришна дас, президент храму міста Маріуполя, розповідає, що в 2014 році, коли почався конфлікт на Донбасі, в ятрі почалися «бродіння», як він висловився. Були ті, які займали проросійську позицію, так само, як ті, які були категорично проукраїнськими. Але старші, які, за словами президента, більш універсально дивляться на світ, для яких немає українців, росіян, американщів, індусів, чоловіків, жінок, ось цим своїм знанням ніби втихомирили громаду і не допустили розколу: «Ми просто зібралися, поговорили, зупинилися на позищії Шріли Прабгупади, ось на цьому, що ми маємо прагнути до єдиного бачення живих істот, розуміти, що зараз хтось $є$ обумовленим, але в глибині душа вона всюди однакова, хоч в тілі нашого друга, хоч в тілі нашого ворога, тому ми домовилися, що ми цю тему взагалі закриваємо». Тож, суперечки всередині маріупольської ятри тривали не більше місяця. Й справді, громада не розкололася, підтримує зв 'язки з усіма іншими ятрами, в тому числі з донецькою.

Відданий Дмитро Пальченко розказував, що спілкувався з відданим із Донецька, який був протилежних поглядів, ніж він сам:

«Уявляєте, на Бгакті Сангамі в 2015 році, на Шацьких озерах коли було, я чув таке від відданих Донецька. Що вони в ополченні служать, стріляють по укропах, потім приходять в храм, моляться. У мене це в голові не вкладалося. Тоді 3 одним відданим із Донецька... «треба йти на Київ, всі дела, танки, громити Київ». Я кажу, «Прабгу , ви відданий, чи хто ви?». Він осікся, «Забудьте, що я казав». «Так ви взагалі думайте, що говорите, йти на Київ, там же живі люди». Це мені відданий на Бгакті Сангамі говорив. Перед Богом говорю, це було. Це все я чув».

Або ще такого ж роду свідчення того ж респондента:

«У мене були розмови після цього вже пізніше з представниками донецької ятри. Я кажу, що ми, наприклад, постували, щоб від нас пішла війна. Ятра постувала у Краматорську на суху у Пандава Екадаш, навіть коли почався обстріл міста, пост не перервали, продовжували читати совмісно магамантру. Через декілька днів війна пішла з Краматорська, відразу вийшли на харінаму на вулиці міста відсвяткувати це. Ви що робили, кажу? Ну, вони нічого не відповідали мені на ці питання».

Також відданий повідомив, що деякі ятри на непідконтрольних Україні територіях розділилися на політичному грунті:

«На півночі Луганської області є ятра, яка розділилася: щосереди збираються ті, хто за Україну, а щовівторка ті, хто за «русский

\footnotetext{
3 Прабгу (із санскр. - «володар») - звернення до чоловіка в Товаристві свідомості Кришни.
} 
мир». Вони проводять ті ж самі яг $\imath^{4}$, знаєте, щоб не сваритися».

У Криму також діють вайшнавські громади. Інформації про їхню діяльність мало, але відомо, що регіональний секретар Товариства Свідомості Кришни в Криму (у нього входять усі центри та нама-хатти 5 в Сімферополі, Севастополі, Ялті, Керчі, Алушті та інших містах). Е. П. приїжджає в Україну на засідання національної ради, на яку збираються всі президенти центрів і храмів в Україні. Крім того, регіональний секретар громад Міжнародного товариства свідомості Крішни в Україні та Молдові Ач'юта Прія дас відповідає не тільки за Україну, а за цілий регіон, до якого, крім України, належать Молдова, Придністров'я, Донецк, Луганськ, Крим. Віддані 3 Криму їздять на фестивалі на материкову Україну і навпаки. Це засвідчив в інтерв ю Дмитро Пальченко, який розповідав, як зустрічав вайшнавів з Криму. Вони йому розказували приблизно те ж, що і вайшнави з Донецька:

«Вони починають розповідати, що зараз нам не можна проводити харінами, що ми в підпіллі. А я кажу, а хіба це добре? Вони кажуть, мовляв, це тимчасово, треба потерпіти. Чого терпіти, кажу їм як кшатрій, давайте ми звільнимо Крим і ви там будете харінами проводити як брагмани. А вони там починають за політику. А я кажу, так ви хочете харінаму проводити, чи ви не хочете ії проводити? Ви хочете змиритися з тим, що

\footnotetext{
${ }^{4}$ Яг'я (із санскр. уајп̃á - «жертва», «відданість», «поклоніння») - загальна назва для всіх ритуалів в індуїзмі, які виконуються біля священного вогню.

${ }^{5}$ Нама-хатта (із санскр. nāma - «ім' я», hatta - «базар») буквально «базар святого імені», в контексті ISKCON невеликі місцеві групи відданих, учасники яких регулярно збираються разом для оспівування священних імен (кіртани), обговорення духовних питань та вшановування прасаду (prasāda) - вегетаріанської їжі, яку перед вживанням пропонують божеству. Нама-
}

у вас заборонені харінами на півострові і всі інші віровизнання, крім російської православної церкви, або ви не хочете? Ви визначтеся. Якщо ви хочете, то ви маєте підтримувати Україну, бо в Україні дозволені всі віровизнання, а в Росії, як ми знаємо, намагалися Бгагават-гіту заборонити i визнати їі екстремістською».

Більшість вайшнавів після початку війни покинули непідконтрольну Україні територію Донбасу. Віддані тікали як в Росію, так і в Україну. Всі українські храми відкрили свої двері для біженців. Віддані зі Сходу знаходили прихисток не лише в храмах у східних областях. Храми міст Західної України також прийняли біженців. Авторка сама стала очевидицею проживання біженців у ретрит-центрі «Новий Маяпур» в Дніпропетровській області в 2015 році та в храмі міста Луцька в 2016 році. Як повідомляв на сайті «Українського фонду допомоги вайшнавським біженцям» (Ukrainian Vaisnava Refugee Fund) Абхіднанда дас, станом на липень 2014 року 17 відданих по всій Україні в рамках кампанії «Український вайшнавський біженець» запропонували прихисток для одновірців. Ашрам 6 (ретрит центр) «Новий Маяпур» в с. Магдалинівка Дніпропетровської області прихистив 33 відданих, 37 відданих поселилися в сім'ях, деякі 3 відданих перебралися в Крим і тимчасово жили там в доволі аскетичних умовах лише до холодного сезону. 6 відданих чекає на

хаттом можуть називати як невелику громаду міста, яка не має свого храму або центру, або ж спонтанні зібрання невеликої групи вайшнавів (найчастіше вдома у когось із відданих), які є частиною великої організованої громади з храмом чи центром.

${ }^{6}$ Ашрам - інституція в індуїзмі, сенс якої полягає в об'єднанні та співжитті прихильників певного бога чи вчителя задля духовної практики. Також слово ашрам в індуїзмі означає приміщення спільного проживання одновірців. 
можливі варіанти розселення. Пізніше, а саме 31 липня 2014 року, Абхінанда Дас повідомив, що загальна кількість відданих, які розселилися за межами непідконтрольних територій сягає більше 100 [Ukrainian Vaisnava]. Уже в серпні 2014 стало зрозуміло, що можливості ретрит-центру вичерпались, адже туди заселили 40 відданих, серед яких переважно жінки і діти, які не мали грошових збережень і не могли взяти 3 собою багато речей. Також центр тоді активно почали готувати до зими, утеплюючи приміщення, які раніше були призначені лише для проживання у теплий сезон. Київ та Київська область стали для біженців (особливо чоловіків) найбільш бажаним місцем поселення, адже тут найбільше можливостей для працевлаштування. Відомо, що більшість відданих із ятри Слов'янська переселилися до Києва. Ті, хто залишилися (а це не більше 10 відданих), не проводять публічних програм та намахаттів в своєму місті, а їздять на всі заходи до сусіднього Краматорська. Те ж можна сказати про Дружківку та інші сателіти Краматорська.

У період окупації Краматорська місцеві вайшнави не проводили жодних публічних заходів. Перша харінама у звільненому місті була проведена вже у 2015 році. Це місто стало не лише адміністративним центром Донецької області, але і центром ISKCON на підконтрольних Україні територіях Донбасу. Віддані з багатьох міст області приїжджають на харінами та недільні програми саме сюди. Також вайшнави краматорської ятри роблять виїзні харінами в Костянтинівку, Дружківку, Слов' янськ та інші міста та селища в Донецькій області.

Благодійність вайшнавів в умовах війни. Ставлення до війни у вайшнавізмі чітко визначене - війни невідворотні, вони є атрибутом епохи деградації - калі-юги, тому всі намагання припинити війни, або якось вплинути на їхній хід просто неможливо. Війна - це породження тама-гуни, якості невігластва, однієї з трьох гун матеріального світу поруч з раджа-гуною (якістю пристрасті) та саттва-гуною (якістю благості). Тому війна сприймається вайшнавами не як боротьба людей різної національної чи релігійної приналежності, а як боротьба людей, які перебувають в гуні невігластва і допускають війну через свою неусвідомленість. Тому вайшнави вбачають свою роль у війні не в тому, щоб ставати на чийсь бік, або своїми діями допомагати одній із сторін, а в тому, щоб трансформувати тама-гуну (якість невігластва) в саттва-гуну (якість благості), а така трансформація досягається трансцендентними засобами - через молитву та служіння Кришні, а також служіння людям, які незалежно від усіх своїх зовнішніх атрибутів (статі, етнічного походження, національності, релігії і т. д.) всі є дживами (душами). Квінтесенцією цієї позищії є слова російського саньясіна Бгакті Віджняни Госвамі, який звернувся до відданих Росії та України в березні 2014 року: «Ми як вайшнави особливо тісно пов'язані одне 3 одним. Шріла Прабгупада справді зробив нас однією сім'єю, незалежно від того, які ми маємо уявлення про другорядні справи цього матеріального світу, одна велика сім’я, яка справді пов'язана нитками любові та духовної спорідненості» [An Appeal]. Розвиваючи цю позицію, треба сказати, що згідно 3 вченням вайшнавів у кожної людини є своя дгарма (обов'язок), в якій розрізняється упа-дгарма - тимчасовий обов'язок - та санатана дгарма - вічний обов'язок. Ці два обов'язки ще називають 
найміттіка дгармою та джайва дгармою, тобто тимчасовим обов'язком та обов'язком душі. Перший - це той, який людина виконує в обумовленому матеріальному світі: сімейний, громадянський. Другий же належить трансцендентному і божественному, це обов'язок людини перед Богом і $є$ первинним по відношенню до тимчасового. Війна стосується тимчасової дгарми, яку теж треба виконувати, але яка другорядна відносно вічної. Брати участь у війні, або ставати на чийсь бік - означає допускати хибну самототожність, ототожнення себе 3 тілом, а не 3 душею, адже національність і громадянство, за уявленнями вайшнавів, це атрибути тіла. Саме тому позиція невтручання в політичні та воєнні справи є принциповою для Товариства свідомості Кришни. Саме 3 цим пов'язана специфіка допомоги вайшнавів в умовах війни.

Кришнаїти принципово не організовували волонтерських місій на фронт, як це робили представники інших конфесій, особливо християнських. Дмитро Пальченко, який займав чітку проукраїнську позицію, пропонував створити в рамках ISCKON волонтерський рух, який допомагав би безпосередньо фронту і військовим, який би «під прапорами Кришни» надавав матеріальну допомогу армії і займався проповіддю на фронті. Відданий навіть продумав деякі деталі - йому дуже хотілося виготовити для волонтерів футболки з написом «Кришна любить Україну». Керівництво Товариства не підтримало, та й не могло підтримати таку ініціативу, бо своє завдання, як вже було сказано, вбачає в трансформації невігластва в благість не шляхом прийняття тієї чи іншої сторони конфлікту i допомоги їй, а трансцендентними методами, які можна класифікувати як недіяльні та діяльні.
До недіяльних віднесемо всю духовну практику, яку виконують вайшнави незалежно від обставин, а також спеціальні молитви, ритуали і практики, спрямовані на вирішення ситуації з війною. Особливо слід звернути увагу на проповідь шляхом розповсюдження літератури. В грудні 2014 року київський храм організував «Марафон Прабгупади», який покликаний був поділитися якомога більшою кількістю книг вчителя, в тому числі й у східних регіонах України. Як повідомив регіональний секретар Товариства Свідомості Кришни в Україні Ач'юта Прія дас, віддані уникають розповсюджувати літературу в східних регіонах України, таких як Донецьк та Луганськ, де ведуться активні бойові дії, адже «... ми не хочемо піддавати ризику життя відданих, ми попросили розповсюджувачів книг покинути небезпечні території та перейти в безпечні місця для білыш ефективної проповіді» [Ukrainian Devotees]. Відданий Пальченко згадував колективний піст, який влаштувала його ятра під час окупації, а також яг 'ï, спрямовані на припинення війни. До діяльних методів можна віднести ті, які носять не лише духовний характер, але і практичний. Вони зорієнтовані на матеріальну допомогу постраждалим від війни, але не їі учасникам. Допустимих для вайшнавів діяльних методів є два проект «Їжа життя» та турбота про покинутих в зоні конфлікту корів.

Приготування та споживання їжі - дуже важлива частина релігійного поклоніння вайшнавів. Адже їжу пропонують Богу i смакуючи прасад вайшнав безпосередньо долучається до божественного буття [Карпицький 2016: 102]. Тому і роздача такої їжі має настільки ж важливе духовне значення для боротьби 3 невіглаством, як $\mathrm{i}$ проповідь віровчення. До божественного 
буття через їжу долучаються не лише ті, хто вже у свідомості Кришни, а і люди, які до неї не належать. Проект «Їжа життя. Донецьк» безпосередньо з війною не пов'язаний. Їжу роздають усім, хто ії потребує, незалежно від національної приналежності чи політичних переконань. Зазвичай це соціально незахищені верстви суспільства пенсіонери, інваліди, безробітні, переселенці, мирні жителі, які постраждали в результаті збройного конфлікту на Сході України. Їжу роздають людям в містах та містечках, цілеспрямованого годування військових ні однієї, ні іншої сторони не проводиться. Саме тому проект «Їжа життя» $\epsilon$ мало не єдиним благодійним проектом, пов' язаним з війною, але, що важливо, лише опосередковано. Втім, є винятки. Як повідомив президент рівненського храму, коли почався конфлікт на Донбасі, їхня ятра відправляла прасад саме для українських солдатів. Таку ініціативу не можна назвати ініціативою організації, радше приватною ініціативою іiі членів, адже вона була несистемною і втілювалася безвідносно до відомих вайшнавських благодійних проектів.

Турбота про корів, яких покинули в зоні конфлікту, також $є$ частиною духовної роботи вайшнавів, адже вона вкладається в загальні уявлення індуїзму про корову як священну тварину. Корова - це не просто священна тварина, а та, яка дає молоко, завдяки якій легше підтримувати вегетаріанську дієту, саме тому із самого початку розвиту ISKCON почали виникати різні екопроекти, спрямовані в тому числі за захист корів та належний догляд за ними. Щороку в різних куточках світу проводяться конференції з цієї тематики. У структурі ISKCON діє Міністерство захисту корів та сільського господарства (ISKCON Ministry of Cow Protection and Agriculture), скорочено IMCPA, яке займається проведенням цих конференцій. Український ISKCON активно підтримує ці проекти, створюючи екопоселення та екоферми. Корови на них мають належний догляд i захищені від забою. Як висловилися президент рівненської громади Вайкунтха Према дас та відданий 3 тієї ж громади Варіштха дас, зараз Товариство свідомості Кришни переживає етап, на якому віддані вчаться не лише спільному поклонінню, а й співжиттю в сільськогосподарських громадах. Тому в Україні з'являється все більше екопоселень 3 гошалами 7 для корів. Варіштха дас, який сам живе в екопоселенні в селі Кармалюківка Одеської області сказав, що «хочуть розвинути програму захисту корів. Тому що для собак, для котів притулки є, щоб їх взяли, або вони там вмерли своєю смертю. Те ж саме зараз зробили в селі Безводному для корів. Оскільки вона священна тварина і краще, коли вона покидає тіло своєю смертю, в наступному житті вона народиться брагманом, ця душа буде людиною і буде священиком». Тому українські вайшнави не могли залишитися осторонь проблеми покинутих у зоні конфлікту корів. Відомо, що в селі Широкіно після початку конфлікту на Донбасі найдовше залишалися так звані «корівники», люди, які чекали отелення до березня 2014 року, але і ті врешті-решт відв'язали тварин і поїхали. Корови розбрелися околицями, якісь підірвалися на мінних полях, якісь попали під обстріли, якихось підібрали жителі сусідніх сіл.

\footnotetext{
7 Гошала (із санскр. gauśālā : “gau” - корова + śālā укриття) - хлів для корів.
} 
Спасіння таких залишених в зоні конфлікту корів в Товаристві свідомості Кришни не набуло вигляду організованого руху, але відомо достеменно, що громада ISCKON Дніпропетровська, яка була активною у цій справі, наймала вантажівки і їхала на фронт рятувати тварин.

Участь вайшнавів у війні. Щоб зрозуміти ставлення вайшнавів до війни, потрібно розрізняти офіційну позицію ISCKON та індивідуальну позицію відданих. Як уже було підкреслено, на офіційному рівні вайшнави дотримуються позиції невтручання й на рівні громади не можуть підтримати ту чи іншу сторону конфлікту. Але на індивідуальному рівні кожен відданий, маючи свободу, сам розпоряджається власним життям і вирішує, як і якою мірою втручається в мирські справи. ISCKON розділяе загальні уявлення індуїзму про варнашраму8 8 вчення про чотири стадії життя людини та чотири прошарки суспільства, але за уявленнями Товариства, варна людини визначається не за народженням, а за здібностями та схильностями. Якщо людині вдається пізнати свою природу, зокрема зрозуміти, до якої варни вона належить, лише це може зробити іï щасливою, навіть якщо вона не має духовної освіти. Тож якщо відданий зрозумів, що за природою він кшатрій, то він швидше реалізує свою природу, будучи солдатом чи управлінщем, ніж монахом чи вчителем. Тому до рішень брати участь у війні з боку окремих відданих Товариство на офіційному рівні ставиться нейтрально - не осуджує, і не схвалює. Вайкунтха Према дас в інтерв ${ }^{\prime}$ ю сказав, що «... це добровільний вибір людини. Але на рівні громади це в

\footnotetext{
${ }^{8}$ Варнашрама (із. санкскр. - varṇāśrama: varṇā -“колір”, “порядок” + āśrama - "свобода від втоми”) - вчення в
}

жодному разі не нав язується. Це не те, що я як адміністративний керівник тисну, що робіть це. Це особиста справа кожного. Це всі переживають, всі патріоти, це вільний вибір людей».

Участь у війні не суперечить вайшнавським принципам, в Бгагават-гіті йдеться про те, що душу неможливо вбити, бо вона вічна. Воювати - обов'язок кшатрія і якщо вайшнав розпізнав свою кшатрійську природу, участь у війні лише послужить іï реалізації. Тому серед вайшнавів $\epsilon$ ті, хто свідомо пішов в армію. Відомо щонайменше про двох відданих - Чанчалу Прабгу 3 Рівного та Дмитра Пальченка 3 Kраматорська. Відомо, що віддані також служать по інший бік барикад. Відданий Дмитро Пальченко так пояснює своє рішення йти в армію: «Тому коли мені прийшла повістка в армію, я прийняв рішення йти в кшатрійську варну, тому що там все чіткіше і правильніше, не так все розмито, тобто я шукаю таку опору, але стараюсь не відхилятися від того, що казав Прабгупада, хоча, як Ісус говорив коли підійшли солдати... «А що нам робити?», «Виконуйте накази, але болю не завдавайте!» Це коли тобі кажуть «розстріляй людину», - це означає просто кулю йому в лоб пустити, а не мучити, катувати там всіляко. Тобто ти маєш виконувати наказ».

Позиція адміністрації ISCKON чітка i однозначна з приводу війни та участі в ній, але всередині громади присутні різні позиції. Відданий Дмитро Пальченко розповідав, що далеко не всі одновірці схвалюють його рішення служити в армії: «Ось ми зараз перебуваємо в храмі київському, і я ось у воєнній формі, в формі кшатрія, життя людини. 
і я цього не цураюсь, я впевнений, що тут є віддані, які незадоволені, тому що вони розділяють ось цю думку пропаганди «русского мира»». Адміністративна та духовна верхівка храму пояснює політичні суперечки серед відданих недостатньою духовною зрілістю, адже, як було сказано, війна та інші справи матеріального світу $є$ другорядними, а віддані, які занадто ними переймаються, просто перебувають на шляху до цього розуміння, але поки не досягли його. «Я коли чую, що віддані починають говорити про політику, про Путіна, починають прославляти Путіна, я їм нічого не пояснюю, але я бачу, що це відданий, повторює магамантру9 ${ }^{9}$, просто віддаляюсь від нього, просто йду. І так роблять всі. Це мені старші порадили так робити і я, в принципі, з самими відданими не воюю. 3 іншими людьми, які не $є$ відданими, просто з сепаратистами, колабораціоністами я буду сперечатися, але якщо я бачу, що це серед відданих, я притримуюсь поради старших».

\section{Українсько-російські контакти в} ISCKON. Перешкодою для українськоросійських контактів є технічні труднощі, пов'язані з перетином кордонів. За свідченнями президента храму міста Маріуполя Мадхави Кришни даса, відданим із їхньої громади легше поїхати на фестиваль у Львів, ніж на російську територію чи в Донецьк, хоча це набагато ближче. Президенту доводиться регулярно бувати на непідконтрольних територіях. Це входить у його обов'язки як адміністратора. Усвідомлення свого службового обов'язку та відчуття відповідальності, зізнається відданий, дозволяє йому успішно долати всі

\footnotetext{
${ }^{9}$ Магамантра або Харе Кришна мантра (із. санкскр. maha - "великий" + mantra - "мантра") - мантра у вайшнавізмі, яка стала головною мантрою ISKCON. Вона складається 36 слів і звучить як «Харе Кришна, Харе
}

труднощі 3 перетином кордону. Але навіть йому це нелегко, не кажучи вже про пересічних відданих, на яких такої відповідальності немає. Тому, як каже Мадхава Кришна дас, для відданих немає жодного сенсу ускладнювати собі життя. «Простіше зараз поїхати в Одесу чи в Коблево 10 , ніж переїжджати оце».

Хоч від Маріуполя до Ростова-на-Дону менше 200 км, зараз на фестивалі туди непросто добратися, адже якщо раніше тут була пряма траса Маріуполь - Ростов-наДону, то зараз вона перекрита, й для того, щоб туди потрапити, треба або навколо всі непідконтрольні Україні території об їхати, що забере багато часу, або через них їхати, маючи всі вище згадувані труднощі на блокпостах. Морського сполучення тут немає ще 3 радянських часів. 3 цих же причин украӥнські вайшнави з інших міст також стали менше їздити в Росію на фестивалі. За словами Вайкунтхи Преми даса, віддані як їздили в Росію на фестивалі, так і їздять, тому про повне припинення контактів між вайшнавами обох держав не йдеться. Політичні переконання також є причиною зменшення інтенсивності контактів, але не основною. Вайкунтха Према дас розповів, як спостерігав мирну взаємодію та співжиття українських та російських вайшнавів у Вріндавані (Індія, УттарПрадеш), вайшнавському паломницькому центрі. На популярному російському вайшнавському фестивалі Садгу-санга, який традиційно проходить в Красноярському краї в поселенні Джубг у 2019 році зібралося більше 5 тис. відданих, в тому числі і з України [Russian Sadhu]. Так само

\footnotetext{
Кришна, Кришна, Кришна, Харе, Харе! Харе Рама, Харе Рама, Рама, Рама, Харе Харе».

10 у Коблево із Криму був перенесений всеукраїнський
} фестиваль «Бгакті Сангама». 
український ретрит в ашрамі «Новий Маяпур», який проводив американський садгу Ніранджана Свамі з 30 липня до 4 серпня 2019 р., відвідали віддані з Росії [Devotees].

До війни в Україну часто приїжджали магараджі11 російського походження, особливо в міста Східної України. 3 початком війни стали їздити менше. Лише магарадж Чайтанья Чандра Чаран проїздом із Німеччини в Росію відвідав 3 програмами Львів, Луцьк і Рівне. Відомо, що російські магараджі зараз їздять переважно на непідконтрольні Україні території.

Спілкування між відданими відбувається також в інтернет-просторі на вайшнавських форумах. Респондент Пальченко розповів про суперечки з російськими відданими - «I коли я питаю у російських відданих: «Крим вкрали?» - Ні, він офіційно...». «Ви брешете, кажу. Ви брагман і ви підтримуєте... Весь світ визнав офіційно анексію. Вкрадена земля, люди вкрадені, техніка, ресурси і т. д. Ви ж кажете протилежне, ви втрачаєте зараз силу, я вам вже не вірю, далі в вашу щирість я не можу вірити. Якби ви сказали, ви знаєте, я знаю, що вкрали, але я не підтримую цю крадіжку, це було би більш правдиво. І я вже як людина не бачу в них оцієї сили, цієї правди брагманічної».

Російський саньясін Бгакті Віджняна Госвамі у зверненні до відданих Росії та України сказав, що це боляче бачити, як вайшнави задіяні в онлайн боях у соцмережах лише тому, що їхні погляди на політичний конфлікт відрізняються, підкреслюючи негативну роль медіа у цьому. «Вони породжують ворожість та ненависть в серцях,

\footnotetext{
11 Магарадж (із санскр. - mahārāja: mahā - "великий”+ rāja - правитель) - у вайшнавізмі магараджами називають відданих, які прийняли саньясу (відречення),
}

а це повністю суперечить тому, що люди мають культивувати в своєму житті - це суперечить любові» [An Appeal]. Тож, суперечок на політичному грунті вайшнавам, орієнтованим на трансцендентне, уникнути не вдалося.

Висновки. Для українських вайшнавів війна на Сході України стала таким же викликом, як і для решти суспільства. Вона поставила перед українськими прихильниками Кришни як суто практичні задачі, так і духовні (світоглядні). Практичні полягали в тому, що український ISKON мав у терміновому порядку забезпечити своїх одновірців-біженців житлом та всім необхідним як на рівні адміністрації та колективних проектів, так і на індивідуальному рівні, коли віддані тимчасово надавали біженцям притулок у себе вдома. Духовні та світоглядні виклики були пов'язані з самовизначенням стосовно війни - як громада в цілому, так і кожен відданий мав так чи інакше вкласти війну у свою картину світу, прийняти якусь позицію, або не приймати жодної.

Проблеми практичного характеру були вирішені шляхом заснування фонду допомоги біженцям, який забезпечив як будівництво нового тимчасового житла для біженців, так і утеплення непристосованих для холодного сезону житлових приміщень. Також бажаною була благодійність в зоні конфлікту у вигляді проекту «Їжа життя» та локального проекту в його межах «Їжа життя. Донецьк», а також турбота про покинутих в зоні конфлікту корів. Благодійницьких проектів, пов'язаних безпосередньо $з$ допомогою армії, не було через чітку

й займаються проповідницькою діяльністю. Інколи магараджами називають не лише саньясінів, а просто вчителів. 
позицію ISCKON про невтручання у справи війни через специфічне бачення вайшнавами їхньої ролі у війні, яка відрізняється від бачення інших конфесій. Виняток становить приватна ініціатива рівненської ятри відправляти на фронт гуманітарну допомогу яка виникла «знизу» і була підтримана адміністрацією храму.

Перед громадами на непідконтрольних Україні територіях, а також в Криму постали практичні турботи легалізації в умовах жорсткого релігійного законодавства.

Що стосується світоглядного виклику, то позиція ISKCON як релігійної організації стосовно подій на Сході України однозначна і передбачувана: вайшнавська громада займає позицію невтручання у справи війни i не приймає жодну із сторін, що детально пояснено вище. Втім, індивідуальна позиція кожного відданого могла збігатися 3 позицією ISKCON, а могла відрізнятися від неї в залежності від особистого досвіду вайшнава, особливо до приходу в Свідомість Кришни. Звісно, далеко не всі віддані змогли абстрагуватися від політики, як до цього закликає вчення. Серед вайшнавів зустрічаємо i проукраїнські, і проросійські погляди. Можна сказати, що на індивідуальному рівні вайшнави в своєму ставленні до війни нічим не вирізняються серед решти населення України, тому позиція вайшнавів відповідає позиції населення в цілому на тих чи інших територіях. Некоректно стверджувати, що на територіях так званих ДНР та ЛНР віддані мають лише проросійську позицію, а на підконтрольних Україні - проукраїнську. 3 відомих причин кожну з них більше чути з того чи іншого боку від лінії розмежування, в той час як протилежну не афішують або замовчують. Яскравим прикладом цього є відданий К. дас - житель
Донбасу, який займає проукраїнську позицію, тісно спілкується 3 донецькою ятрою, але не афішує ऑї в Донецьку 3 міркувань безпеки. Таким чином для вайшнавів основний світоглядний виклик війни - це навчитися займати нейтральну позицію, як до цього закликає вайшнавізм. Треба сказати, що вайшнави успішно відповіли на цей виклик - по-перше, в громадах майже не відбулося розколів (відомо, що лише деякі ятри на непідконтрольних Україні територіях близькі до розколу); по-друге, вайшнави по обидва боки від лінії розмежування не припинили спілкуватися між собою, так само як 3 вайшнавами Криму, по-третє, воєнний конфлікт на Сході України не завадив контактам та дружньому ставленню одне до одного українських та російських вайшнавів, як це сталося, наприклад, між деякими протестантськими церквами обох країн. Хоча інтенсивність таких контактів зменшилася, але радше через технічні причини, ніж світоглядні.

\section{Список літертури}

Карпицкий, Н. Н. (2018). Евангельская церковь и «русский мир». В: Мелешко, А., Черенков, М. (ред.). Гонения на Донбассе. Свобода вероисповедания и юридическое сопровождение иерквей (Миссия в Евразии: опыт и новые инициативы евангельских изерквей. Часть 8). Исследовательская инициатива «Re-Vision». K: Mission Eurasia. 43-62.

Карпицкий, Н. Н. (2016). Уникальность религиозного опыта в вайшнавизме ISKCON. B: Збірка матеріалів IV та V Міжнародноі релігієзнавчої школи «Вайщнавська традиція крізь століття» 2014 - 2015 рокіВ, Випуск 2. Луцьк: Друкмаркет. 93-115. 
Косяк, С. Н. (2018). Донбасс, которого ты не знал. Дневник священника. Книга первая. Киев: Издатель Заславский А.Ю. 188 с.

Закон «О свободе совести и о религиозных объединениях (с изменениями, внесенными Законом Луганской Народной Республики от 20.08.2018 № 252-II)» (2018). URL:

http:/ /0s.nzzwy3tsfzzxk.cmle.ru/zakonodatelstvo /normativno-pravovaya-baza/5741/ (Дата звернення: 18. 04. 2020).

Закон «О свободе вероисповедания и о религиозных объединениях (С изменениями, внесенными Законами от 10.02.2017 № 172-IНС, от 13.04.2018 № 224-IHC, от 31.08.2018 № 246-IHC, от 03.08.2018 № 251-IHC, от 11.10.2019 № 63-IIHC, от 22.11.2019 № 68-IIHC)».(2016). Принят Постановлением Народного Совета 24 июня 2016 года. URL:

https:/ / dnrsovet.su/zakonodatelnayadeyatelnost/prinyatye/zakony/zakon-donetskojnarodnoj-respubliki-o-svobode-veroispovedaniyai-religioznyh-obedineniyah/ (Дата звернення: 18. 04. 2020).

Пищуа жизни. Донеик. URL:

http:/ / foodforlifedonetsk.com (Дата звернення 05. 01. 2020).

Проект по реконструкиии Донецукого храма ИСККОН. URL: http:/ / krishna.dn.ua/ proekt-porekonstruktsii-donetskogo-hrama-iskkon/ (Дата звернення: 05. 01. 2020).

Релігійні організації в Украӥні (станом на 1 січня 2008 p. (2008). Релігійно-інформаційна служба України. URL:

https://risu.org.ua/ua/index/resourses/statistics /ukr2008

Звіт про мережу церков і релігійних організацій $b$ Україні станом на 01.01.2018 р. Форма 1.

Релігійно-інформаційна служба України. (2018). URL:

https://risu.org.ua/ua/index/resourses/statistics /ukr_2019/75410/

Федеральный закон «О свободе совести и о религиозных объединениях» (последняя редакция) (2019). URL:

http://www.consultant.ru/document/cons_doc_L AW_16218/

Федеральный закон "О внесении изменений $b$ Федеральный закон "О противодействии терроризму" и отдельные законодательные акты Российской Федерации в части установления дополнительных мер противодействия терроризму и обеспечения общественной безопасности. От 6 июля 2016 года № 374-Ф3. (2016). URL: http://www.consultant.ru/document/cons_doc_L AW_201078/

An Appeal to the Devotees of Ukraine and Russia. URL: https://iskconnews.org/an-appeal-to-thedevotees-of-ukraine-and-russia,4314/ (Retrieved December 15, 2019).

Devotees Learn About Guru-Disciple Relationship at Ukraine Retreat. URL: https:/ / iskconnews.org/anappeal-to-the-devotees-of-ukraine-andrussia,4314/ (Retrieved December 15, 2019).

Russian Sadhu Sanga Festival Kicks Off as 5,000 Devotees Flood to Black Sea. URL:

https:/ / iskconnews.org/russian-sadhu-sangafestival-kicks-off-as-5000-devotees-flood-to-blacksea,7079/ (Retrieved December 15, 2019).

Ukrainian Devotees Distribute Krishna's Message in War Torn Region. URL:

https:/ / iskconnews.org/ukrainian-devoteesdistribute-krishnas-message-in-war-tornregion,4733/ (Retrieved December 15, 2019).

Ukrainian Vaisnava Refugee Fund. URL: https://sites.google.com/a/niranjanaswami.org/u krainian-vaisnava-refugee-fund/updatedinformation (Retrieved January 3, 2020).

\section{References}

Karpitsky, N.N. (2018). The Evangelical Church and the "Russian world". In: (ed.) A. Meleshko, M. Cherenkov. Persecution in Donbass. Freedom of religion and legal support of churches (Mission in Eurasia: experience and new initiatives of evangelical churches. Part 8). Re-Vision Research Initiative. K: Mission Eurasia. 43-62.

Karpitsky, N.N. (2016). The uniqueness of religious experience in Vaishnavism ISKCON.In: Collection of materials of the IV and V International School of Religious Studies "Vaishnava tradition through the centuries" 2014 - 2015. Issue 2. Lutsk: Print Market. 93-115.

Kosyak, S.N. (2018). Donbass, whom you did not know. Priest's diary. The first book. Kyiv: Publisher Zaslavsky A.Yu. 188 p. 
Law "On Freedom of Conscience and Religious Associations (as amended by the Law of the Luhansk People's Republic of 20.08.2018 № 252-II)" (2018). URL:

http:/ /0s.nzzwy3tsfzzxk.cmle.ru/zakonodatelstvo /normativno-pravovaya-baza/5741/ (Access date: 18. 04. 2020).

Law "On Freedom of Religion and Religious Associations (As amended by the Laws of 10.02.2017 № 172-INS, of 13.04.2018 № 224-INS, of 31.08.2018 № 246-INS, of 03.08.2018 № 251-INS , from 11.10.2019 № 63-IINS, from 22.11.2019 № 68-IINS) ». (2016). Adopted by the Resolution of the People's Council on June 24, 2016. URL:

https://dnrsovet.su/zakonodatelnayadeyatelnost/prinyatye/zakony/zakon-donetskojnarodnoj-respubliki-o-svobode-veroispovedaniyai-religioznyh-obedineniyah/ (Access date: 18. 04. .

Food of life. Donetsk. URL:

http:/ / foodforlifedonetsk.com (Access date 05. 01. 2020).

Project for the reconstruction of the Donetsk temple ISKCON. URL: http:/ / krishna.dn.ua/ proekt-porekonstruktsii-donetskogo-hrama-iskkon/ (Access date: 05. 01. 2020).

Religious organizations in Ukraine (as of January 1, 2008) Religious Information Service of Ukraine URL:

https://risu.org.ua/ua/index/resourses/statistics /ukr2008

Report on the network of churches and religious organizations in Ukraine as of January 1, 2018. Form 1. Religious Information Service of Ukraine. (2018). URL:

https://risu.org.ua/ua/index/resourses/statistics /ukr_2019/75410/

Federal Law "On Freedom of Conscience and Religious Associations" (latest edition) (2019). URL:

http://www.consultant.ru/document/cons_doc_L AW_16218/

Federal Law "On Amendments to the Federal Law" On Countering Terrorism "and Certain Legislative Acts of the Russian Federation Concerning the Establishment of Additional Measures to Counter Terrorism and Ensuring Public Security. As of July 6, 2016 № 374FZ. (2016). URL: http http://www.consultant.ru/document/cons_doc_L AW_201078/

An Appeal to the Devotees of Ukraine and Russia. URL: https:/ / iskconnews.org/an-appeal-to-thedevotees-of-ukraine-and-russia,4314/ (Retrieved December 15, 2019).
Devotees Learn About Guru-Disciple Relationship at Ukraine Retreat. URL: https:/ / iskconnews.org/anappeal-to-the-devotees-of-ukraine-andrussia,4314/ (Retrieved December 15, 2019).

Russian Sadhu Sanga Festival Kicks Off as 5,000 Devotees Flood to Black Sea. URL:

https:/ / iskconnews.org/russian-sadhu-sangafestival-kicks-off-as-5000-devotees-flood-to-blacksea,7079/ (Retrieved December 15, 2019).

Ukrainian Devotees Distribute Krishna's Message in War Torn Region. URL:

https://iskconnews.org/ukrainian-devoteesdistribute-krishnas-message-in-war-tornregion,4733/ (Retrieved December 15, 2019).

Ukrainian Vaisnava Refugee Fund. URL: https:// sites.google.com/a/niranjanaswami.org/u krainian-vaisnava-refugee-fund/updatedinformation (Retrieved January 3, 2020). 